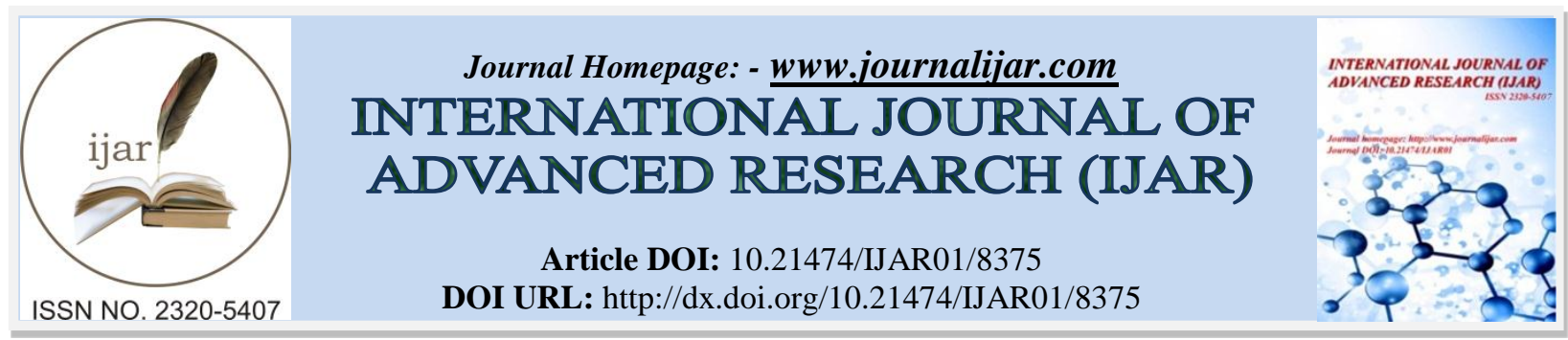

RESEARCH ARTICLE

\title{
THE THIAROYE AQUIFER IN SENEGAL: USABLE GROUNDWATER RESOURCES FOR DRINKING OR IRRIGATION?.
}

Saïdou Ndao ${ }^{1,2}$, Papa Babacar Diop Thioune ${ }^{1,3}$, Alassane Ba ${ }^{1}$ and El Hadji Bamba Diaw ${ }^{1}$.

1. Laboratory of Sciences and Technology of Water and Environment (LaSTEE), Polytechnic School of Thies BPA 10 Thies, Senegal.

2. Université of Thies, Faculty of Science and Technology, City Malick Sy, BP 967, Thies, Senegal.

3. University of Thies, Higher Institute of Agricultural and Rural Training (ISFAR) PO Box 54, Bambey, Senegal.

\section{Manuscript Info}

n.......................

Manuscript History

Received: 10 November 2018

Final Accepted: 12 December 2018

Published: January 2019

Key words:-

Senegal, Thiaroye aquifer, nitrification, water pollution, drinking, irrigation.

\begin{abstract}
The Thiaroye drillings provided for a long time the supply of drinking water to the Dakar region. However, faced with the combined effects of salted bevel advancement and groundwater pollution, state authorities were led to stop their functioning. This led to a drop in the production of drinking water on the one hand, and favored, on the other hand, the recurrence of floods due to the rise of the groundwater level, resulting in the birth of another form of pollution: nitrification of the waters of the Thiaroye aquifer. This phenomenon has many and varied causes mainly related to a lack of waterproofness of septic tanks, the presence of a big cattle enclosure and a cemetery in the area. Their direct communication with the flush sheet is not without consequences on the immediate environment. Indeed, physicochemical analyzes carried out on the water samples taken from about ten piezometers have revealed that the level of the aquifer has, in some places, reached $500 \mathrm{mg} / \mathrm{l} \mathrm{far}$ exceeding the drinking water standard of $50 \mathrm{mg} / \mathrm{l}$ fixed by WHO. As a result, this water has become unfit for human consumption. It is currently used in irrigation.
\end{abstract}

Copy Right, IJAR, 2018,. All rights reserved.

\section{Introduction:-}

Since the 1950s, Dakar, for the most part, was supplied with drinking water by the Thiaroye area. This zone with 8 drillings available produced an average daily flow of $17000 \mathrm{~m}^{3} / \mathrm{d}$. Over the years, a high degree of pollution has been observed. In fact, the nitrate content of the Thiaroye groundwater was more than the $50 \mathrm{mg} / \mathrm{l}$ defined by WHO (WHO, 1994; DGPRE, 2010).

This progressive chemical contamination, which is accompanied by bacteriological pollution, endangered the water resources of the peninsula and the health of the populations who consume the well water directly (SONES, 2012; NDAO, 2012; DIAW et al., 2016). Until 2014, only 2 drillings named F17 and F19 were in service; others have been progressively abandoned because of high levels of nitrates (DGPRE, 2010; SONES, 2012). The average operating flow is maintained at about $2000 \mathrm{~m}^{3} / \mathrm{d}$ with these 2 drillings. Faced with a public health problem, the State of Senegal decides to restart the six other drillings, with a view to serving market gardeners. This decision will also restore to the populations the some $11000 \mathrm{~m}^{3} / \mathrm{d}$ of water taken from the profit of the market perimeters in the quota

\section{Corresponding Author:-Saïdou Ndao.}

Address:-Laboratory of Sciences and Technology of Water and Environment (LaSTEE),

Polytechnic School of Thies BPA 10 Thies, Senegal. 
coming from Keur Momar SARR (KMS), locality where is located the station of potabilisation of the water taken from the lake of Guiers, originally intended for Dakar population (DGPRE, 2010; SONES, 2012).

This article aims to verify the nitrate content of the Thiaroye aquifer to gain insight into its potability and the possibility of using it for irrigation.

\section{Material and Methods:-}

\section{Study Area}

The Thiaroye aquifer is located near Dakar, in the most populated city of Senegal, Pikine (SONES, 2012; NDAO, 2012; DIAW et al., 2016; Faye, 2013). It is limited to the south-west by a piezometric ridge separating it from the infrabasaltic aquifer located in the head of the peninsula, in the west by the oceanic limit, to the south-east by the tertiary marly substratum that outcrops from Mbao and to the north-east by the Tamna depression, which separates it from the groundwater of the North Coast.

It belongs to the superficial aquifer system of the Senegalese basin (Fig 1). It forms the western part of the Quaternary sand groundwater (Diompy, 2011; NDAO, 2012; Faye, 2013).

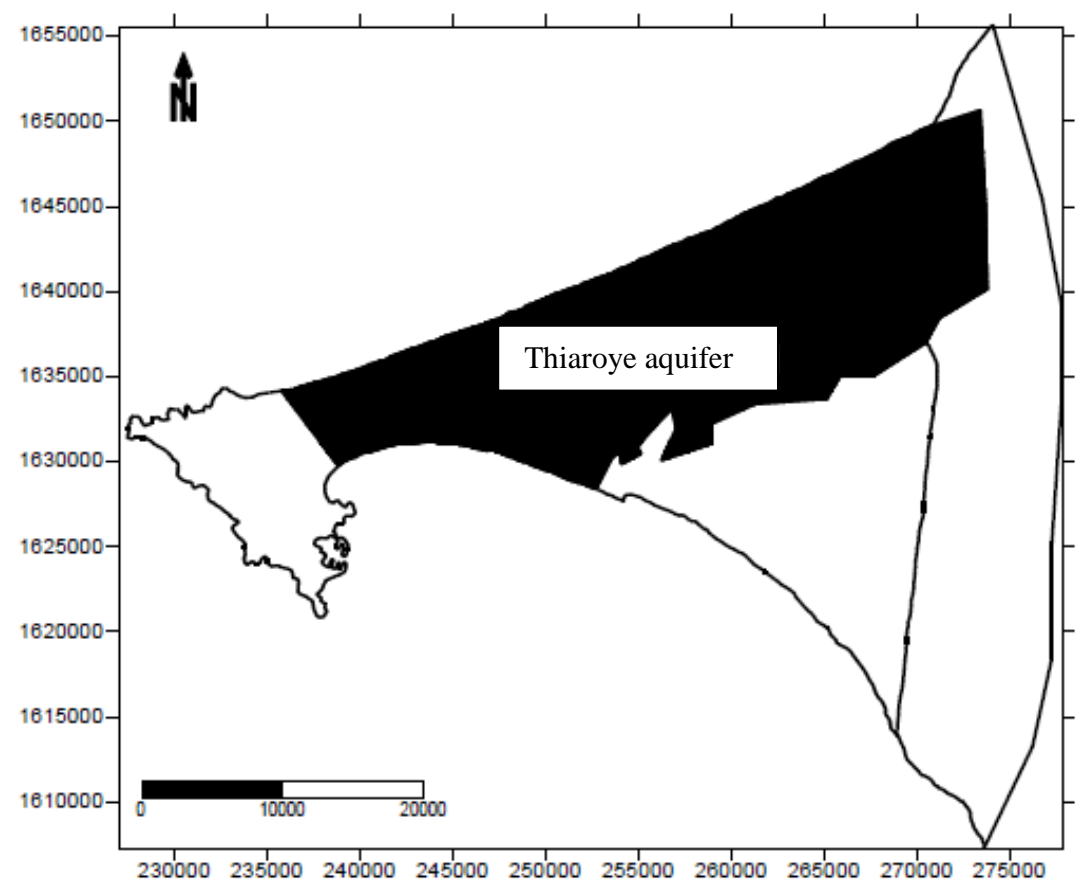

\section{Geomorphological context}

Fig 1:-localization of groundwater of Thiaroye

Quaternary sand formations, whether marine or continental, behave from a hydrogeological point of view as a single reservoir (DGPRE, 2010; SONES, 2012). But this reservoir presents some particularities :

1. without side walls, it is in direct contact with the salty waters of the ocean;

2. its thickness, essentially related to the morphology of its impermeable substratum, is not constant;

3. its permeability, depending on the nature of the aquifer formations, is variable.

This unique reservoir, due to the irregularity of the equilibrium water surface, is divided into independent basins (low areas), separated by watersheds (Diompy, 2011; Faye, 2013).

At the level of the sandy massif joining the head of the peninsula to the mainland, we have the juxtaposition of three dune systems of different ages:

1. the first system is the ogolian dune massif. Formed by dunes of orientation [South-West] - [North-East], it is distinguished by the presence of the hydrographic network of Niayes. The groundwater of the dune massif, which we see flush in the Niayes, is on the whole very soft. However, it is affected by saltwater intrusions whose origins are diverse.

2. the second, which is a coastline, isolates the lagoons of the ocean. Indeed, by wind migration, it filled the lagoons and then rests on the ogolian dune massif. It is limited to a littoral fringe of a few hundred meters. 
3. the third joined to the second, borders the coastline and ends with a low beach.

These formations are based on an impermeable substratum which, flush on the south coast from Grand Mbao, sinks towards the north and the west. Its general appearance is that of an inclined plane towards the north-west.

\section{Hydrogeological context}

The surface of the substratum has depressions which are filled by deposits of aquifers. The inclination of the bedrock towards the northwest influences the direction of the water flow of the groundwater (Diompy, 2011; Faye, 2013).

The wall of the Thiaroye aquifer consists essentially of lower to middle Eocene marls. The morphology of this substratum describes a surface inclined towards the northwest, hence:

1. from the coast $+10 \mathrm{~m}$ to Mbao to the $-60 \mathrm{~m}$ coast along the northern coastline;

2. from the coast $-65 \mathrm{~m}$ at the crow's feet in the west to the coast $-95 \mathrm{~m}$ in the area of Kayar to the east.

The hollow form of the Thiaroye basin results from its exploitation. Originally, the aquifer was dome-shaped and the flow was centrifugal to the ocean (north and south) and to the Cambérène-Dagoudane-Pikine depression (to the west). The direction of flow varies according to the zones:

1. west of the Thiaroye Basin, the flow is southerly and northerly from an east-west watershed;

2. to the south, from the Boun and Niacoulrab domes, the waters drain towards the drainage zone constituted by the Niayes of Grand Mbao and Petit Mbao;

3. in the north, the flow as a whole [north- (north-west)] - [south- (south-east)] is mainly in the profile of lakes and lagoons that function in evaporation drainage zone (Diompy, 2011).

\section{Water quality of the groundwater}

The evolution of the mineralization of the waters obtained from the measurement campaigns shows [7] : a mineralization which remains important in Mbao, but which decreases in the area of Hann, an increase in mineralization in the area of Thiaroye and Pikine-Dagoudane which reached approximately $500 \mathrm{mg} / \mathrm{l}$ and a strong evolution between Deni, Niayes, Beer Thialane and in the Keur Massar area where the mineralization reached 1000 $\mathrm{mg} / \mathrm{l}$.

However, it should be noted that the mineralization in the Thiaroye area is not related to saline invasion, but rather to pollution due to the high nitrate content of the water (Diompy, 2011).

The nitrate ions that represent the highest degree of oxidation in the nitrogen cycle vary in the Dakar water table between $0.55 \mathrm{mg} / \mathrm{l}$ and $800 \mathrm{mg} / \mathrm{l}$ (Fig. 2). The lowest levels are observed west of the region where the aquifer is captive (covered by basaltic flows) and deep, and at Cambérène where there is a piezometric dome involving dilution phenomena. The high levels are found in the peri-urban area (Thiaroye-Pikine) where the values are well above the maximum allowable concentration of $50 \mathrm{mg} / \mathrm{l}$ defined by WHO. It should be remembered that water containing excessive levels of nitrates can cause in consumers (children) methemoglobinemia which corresponds to the oxidation of hemoglobin methemoglobin unable to ensure the transport of blood oxygen to tissues (WHO, 1994; SONES, 2011; Coll, 2005).

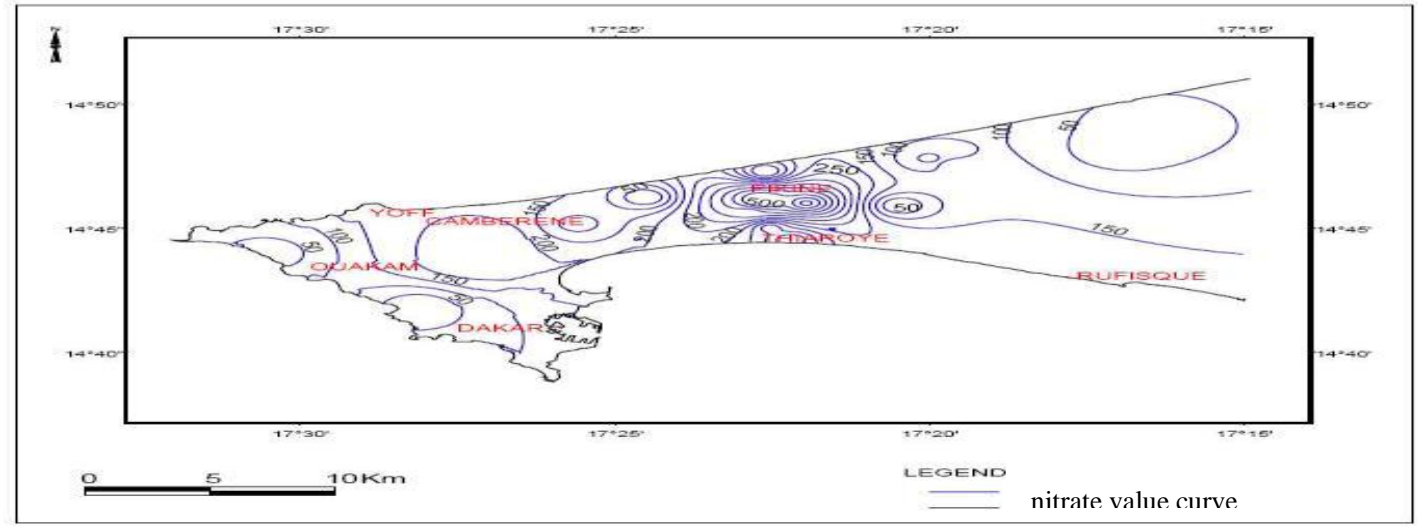

Figure 2:-spatial apportionment of nitrate in Thiaroye's sheet 
In addition, nitrates are a good indicator of organic pollution because the mineralization of organic nitrogen can lead to the formation of nitrate ions (by oxidation) through intermediate steps (ammonium and nitrites). In the peri-urban zone, this nitrogen pollution is essentially anthropogenic (WHO, 1994; Diompy, 2011; Faye, 2013). The qualitative study of the aquifer shows a content of nitrate ions which, as indicated in Table 1, greatly exceeds the allowable values of the WHO. Indeed, the quasi-non-existence of an adequate sanitation network, the way in which domestic garbage and faeces are disposed of would have led to a drastic increase in the level of nitrate, which currently exceeds $50 \mathrm{mg} / \mathrm{l}$ in some localities. The results of the work that has been done on the origin of the high nitrate content in the aquifer have shown that the pollution of the latter is due to the mineralization of organic waste. The fecal influence is confirmed by the high levels of faecal coliforms that reach up to 501 coliforms per milliliter. The use of pesticides in market gardening activities (insecticides, acaricides, nematicides, herbicides, fungicides, etc.) has aggravated the contamination of the aquifer with the progressive infiltration of the excess nitrate supplied to the plants (Cissé, 2000; Addo et al., 2011).

Table 1:-nitrate content in Thiaroye grounwater

\begin{tabular}{|c|c|c|}
\hline Production networks & $\begin{array}{c}\text { Nitrate level } \\
(\mathrm{mg} / \mathrm{l})\end{array}$ & Nitrate rate acceptable by WHO (mg/l) \\
\hline Thiaroye Forage F17 bis & 479 & 50 \\
\hline Thiaroye Forage F 19 bis & 598.5 & 50 \\
\hline
\end{tabular}

\section{Pollution sources of the Thiaroye groundwater}

Identifying sources of contamination is the first important step in controlling groundwater pollution. In the Dakar region, nitrogen pollution is mainly of domestic origin. In fact, the absence or insufficiency of sanitation is the main cause of contamination of the aquifer by nitrates. Organic wastes from defective latrines and wild garbage dumps are transformed by mineralization into nitrates that can easily reach the groundwater because they are not absorbed by the fine particles in the soil. Indeed, previous studies have shown that $90 \%$ of households evacuate household waste through cleaning companies, $5 \%$ evacuate them by landfill and $5 \%$ evacuate them by deposition on the ground or by incineration (DGPRE, 2010; SONES, 2012; Faye, 2013).

With regard to wastewater, $90 \%$ of households discharge wastewater directly onto the ground and $10 \%$ of households dump them in a hole they dig into the ground.

As for the elimination of faeces, $40 \%$ of dwellings use latrines, $40 \%$ of dwellings use wells lost and $20 \%$ of homes dispose of faeces in holes in the ground or at public washrooms that are rarely functional due to lack of maintenance (SONES, 2012; Faye, 2013).

Alongside these active sources, other potential sources of contamination have been identified: the Mbeubeuss landfill, the Thiaroye cemetery and the Thiaroye fair.

\section{The Mbeubeuss landfill}

Initially, the Mbeubeuss landfill was intended to receive only refusals from the Mbao composting plant. It was with the closure of the Hann dump in 1970 that Mbeubeuss began receiving almost all the urban waste collected in the Dakar agglomeration. The landfill receives about 3000 cubic meters of solid waste per day distributed as follows : $93 \%$ of household and similar waste, $6 \%$ of industrial waste and $1 \%$ of biomedical waste (DGPRE, 2010; SONES, 2012).

Added to this is the clandestine waste because the site is accessible due to the lack of fence.

The Thiaroye aquifer extending beneath this landfill presents a certain vulnerability to pollution because of its shallow depth and the nature of the reservoir consisting essentially of highly permeable sandy materials facilitating the very rapid transfer of pollutants into the aquifer (DGPRE, 2010; SONES, 2012).

\section{The Thiaroye Cemetery}

It is a place of accumulation of dead organic matter, thus a privileged medium for the study of the pollution of the underlying groundwaters by the nitrates considering the process of the transformation of the organic matter in nitrates $\left(\mathrm{NO}_{3}^{-}\right)$by mineralization (Cissé, 2000; Addo et al., 2011; AKe et al., 2009; AFNOR, 1997; Ayers and Wescott, 1988; Richards, 1954; DEBIECHE , 2002; ROUABHIA et al., 2004, 2006, 2008; Aller et al., 1987). 


\section{The cattle enclosure of Thiaroye}

It is located on the road to Rufisque at Km 16.5 between Mbao and Thiaroye, It is a place of sale of livestock (sheep, oxen), where the droppings of animals can constitute point pollutants (Faye, 2013).

Figure 3 shows the main pollutants.

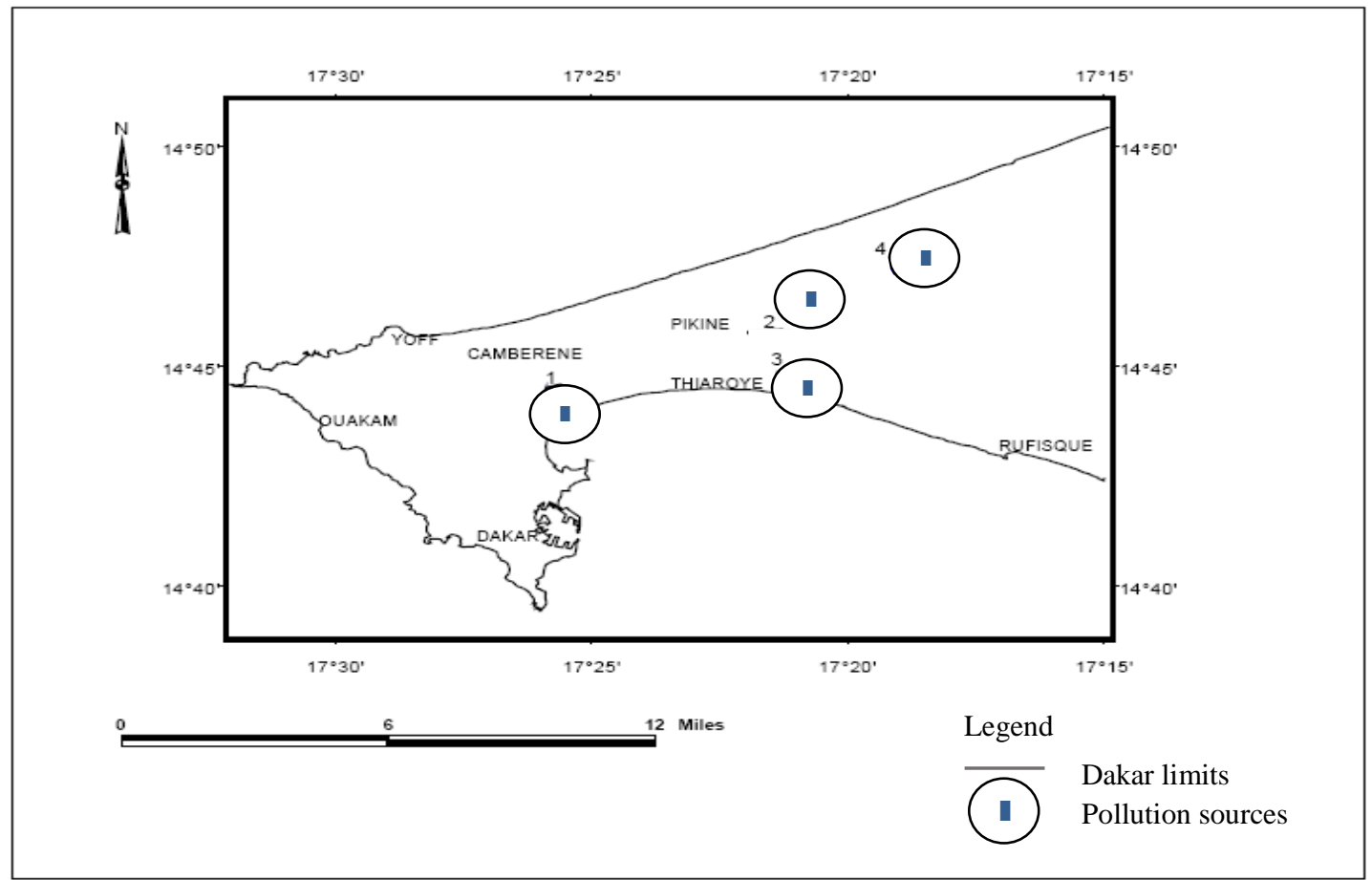

Fig 3:-spatial distribution of pollution origins in Dakar urban sheet: from west to east, flooding area in HannMariste (1), Thiaroye cemetery (2), cattle enclosure (3), Mbeubeuss waste's reject (4)

\section{The role of floods in the process of contamination of Thiaroye groundwater}

The Niayes zone also poses the problem of runoff in a topography marked by the presence of several basins. The absence of drainage or infiltration equipment directly exposes populations to waters converging towards low points (DGPRE, 2010; SONES, 2012; Faye, 2013). When the rise of the groundwater is combined with heavy rains, dwellings in the depressions are severely affected. Stagnant water then mixes with wastewater from septic tanks and drastically increases the risk of waterborne diseases and promotes nitrification of groundwater (Cissé, 2000; Addo et al., 2011; AKe et al., 2009; Ayers and Wescott, 1988; DEBIECHE, 2002; ROUABHIA et al., 2004, 2006, 2008).

\section{Salinization of soils of the Niayes}

The Niayes zone accounts for nearly $80 \%$ of Senegal's vegetable and horticultural production. Irrigation is a key component of production. Even if it is not essential every year, it is an investment that reduces the risks associated with climatic hazards in market gardening production (Aller et al., 1987; Ribero, 2003). In order for water to be used without problems for irrigation, it must meet certain quality criteria, both physical and chemical. It must meet the standards in force stipulated in the WHO Guidelines for Groundwater Reuse Irrigation [1]. The quality of the water is related, among others, to the dissolved salts they contain which in some pedoclimatic contexts can accumulate in the root zone. This results in soil contamination and a profound change in physical and chemical properties that can lead to infertility with respect to agricultural production (salinization or alkalization). This sterility linked to the high concentration of the salt soil solution results in various detrimental effects as increased osmotic pressure, which makes it difficult for the roots of plants to extract water from the soil, toxicity of certain ions for plants and soil degradation (increase in $\mathrm{pH}$, decrease in hydraulic conductivity).

The risks of salinization of certain soils related to the presence of dissolved salts in irrigation water are assessed using two main parameters: the SAR (Sodium Adsorption Ratio) and the percentage of sodium (\% Na) (Richards, 1954; Russo, 1988; Ndiaye et al., 2000). 


\section{SAR:}

Depending on the concentration and type of ions present in the water, the clay can pass from the flocculated state to the dispersed state. The dispersed state is essentially in the presence of a low salt concentration and a high percentage of sodium; as a result, soils become compact and asphyxiating to plants, and soil hydraulic conductivity drops sharply. To assess the risk linked to an excessive sodium content (alkaline risk), the concentration of $\mathrm{Na}+$ ions (dispersion factor) and that of $\mathrm{Ca} 2+$ and $\mathrm{Mg} 2+$ ions, which are flocculation agents, are compared by means of the following parameter:

$$
S A R=\frac{N a^{+}}{\sqrt{\left(C a^{2+}+M g^{2+}\right) / 2}}
$$

The different cations are in meq/l.

SAR is the sodicity of water (equation 1), which translates the water's property of modifying the proportion of exchangeable cations in a soil and increasing in particular the proportion of sodium when this water is in prolonged contact with the soil.

\section{Percentage of sodium (\% Na):}

The evaluation of sodium concentration is important for irrigation because $\mathrm{Na}+$ decreases soil permeability. Indeed, when the sodium concentration is high in the irrigation water, the $\mathrm{Na}+$ tends to be absorbed by the clay particles, displacing the ions of $\mathrm{Ca} 2+$ and $\mathrm{Mg} 2+$. This process of exchanging sodium for calcium and magnesium in water reduces the permeability of the soil and possibly leads to poor drainage capacity of the soil. The percent sodium values are given by the following equation (2):

$$
\% \mathrm{Na}=\frac{\mathrm{Na}+\mathrm{K}^{+}}{\mathrm{Ca}^{2+}+\mathrm{Mg}^{2+}+N a^{+}+K^{+}} \times 100
$$

The different cations are in $\mathrm{meq} / 1$

\section{Results And Discussions:-}

We used the ARC VIEW software to establish the vulnerability map of the aquifer from the nitrate levels determined at 21 points of the aquifer. Depending on the value of the rate, the zone is divided into four classes (very low, low, medium or high) and each is assigned a weight. Fig. 4 shows the result obtained.

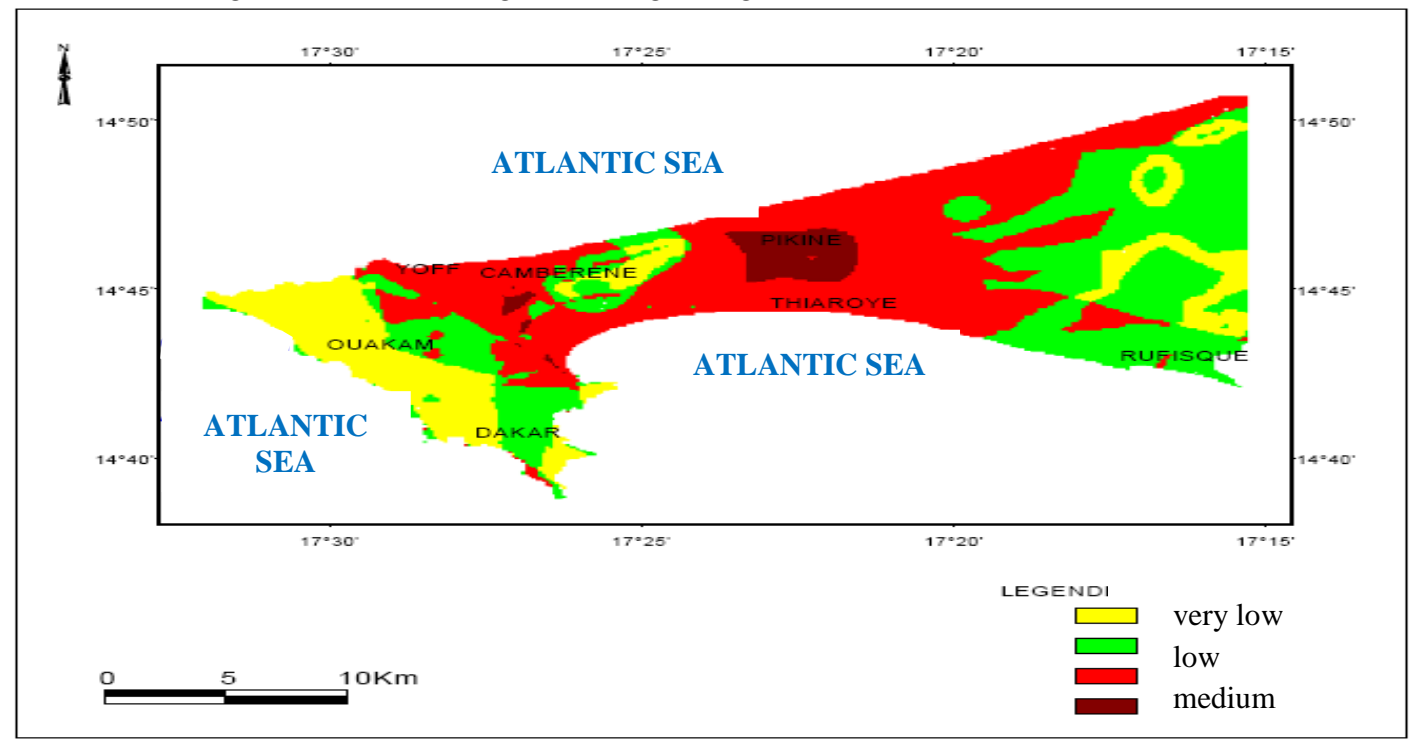

Fig 4:-localization of ground water vulnerability to pollution in Thiaroye

This vulnerability card shows:

1. a zone of very low, low vulnerability, in the West of the region, at the head of the peninsula, in the East and at Cambérène; 
2. at the head of the peninsula, the infra-basaltic aquifer, thus captive, seems well protected by pollution coming from the surface;

3. in the East, steep slopes encourage runoff from surface water at the expense of infiltration to the water table;

4. at Cambérène, a piezometric dome;

5. an area of moderate vulnerability in a large part of the peri-urban zone characterized by the absence of sanitation;

6. an area of high vulnerability, located in the Thiaroye-Pikine basin characterized, in addition to a lack of sanitation, by a shallow groundwater.

Thus, we can note that the Dakar groundwater, very much in demand for the water supply of the region, is very polluted in its eastern part. This nitrogen pollution could expand to the west if effective measures are not taken. In general, it can be said that the nitrogen contamination of the open water and the threat of salted bevel advancement in the infra-basaltic aquifer seriously endanger the water resources of the Dakar region.

To which policy of use of this water resource?

The calculated SAR values in the study area ranged from 0.67 to 5.74 (Table 2).

Table 2:-SAR value in studied sample

\begin{tabular}{|c|c|c|}
\hline Sample points & Localities & SAR \\
\hline Pts 02 & Déni B. Ndao & 5.74 \\
\hline P 2.6 & Boune & 3.00 \\
\hline P 2.7 & TivaounePeulh & 1.66 \\
\hline Pts 58 & Mbeubeuss & 3.74 \\
\hline Pts 58 b & Mbeubeuss & 2.42 \\
\hline Pts 128 & Wayambame & 1.06 \\
\hline Pts 202 & Koumoune & 5.57 \\
\hline Pts 215 & Golam & 1.12 \\
\hline Pts 232 & Kaniack & 2.93 \\
\hline Pts 235 & Bambilor & 4.56 \\
\hline P 2.5 & CornicheGuédiawaye & 2.11 \\
\hline F17 & Marché Thiaroye & 3.73 \\
\hline F 19 & Thiaroye & 2.81 \\
\hline F 21 & Thiaroye & 2.33 \\
\hline F 22 & Thiaroye & 2.56 \\
\hline P 1 & Technopole & 2.37 \\
\hline P 4 & Pikine & 4.32 \\
\hline P 21 & Yeumbeul & 4.50 \\
\hline PS 1 & Sangalkam & 0.90 \\
\hline PS 4 & Santhe Mame Gor & 1.05 \\
\hline
\end{tabular}

The ranking of groundwater samples based on SAR values is presented in Table 3.

Table 3:-classification of water quality according to SAR

\begin{tabular}{|c|c|c|c|}
\hline Classe & Rank & Number of samples & Percentage \\
\hline Excellent & $\leq 10$ & 21 & 100 \\
\hline Good & $10-18$ & 0 & 0 \\
\hline Doubtful & $18-26$ & 0 & 0 \\
\hline Unfit & $\geq 26$ & 0 & 0 \\
\hline
\end{tabular}

The SAR values of all samples are in the excellent category range. The Wilcox (1948) salinity plot (Fig. 5) was used to plot SAR based on electrical conductivity (EC) to better classify the waters. The diagram indicates that $11.11 \%$ of the samples of the zone are in C1S1, which corresponds to the class of good to medium quality waters (low sodium low salinity type). These waters can be used for irrigation on several crops in different soils with a low probability that the soil salinity increases as well as the sodium level of the soil. $36.11 \%$ of the samples fall into C2S1, 
indicating medium to poor water quality. They can be used with caution in irrigation but this requires drainage with leaching dosing or with gypsum. $38.89 \%$ of the samples are in C3S1, revealing high salinity sodium-type groundwater. The rest of the samples representing $13.89 \%$ falls in $\mathrm{C} 4 \mathrm{~S} 2$, these waters have a very high salinity. Therefore, they are not suitable for irrigation.

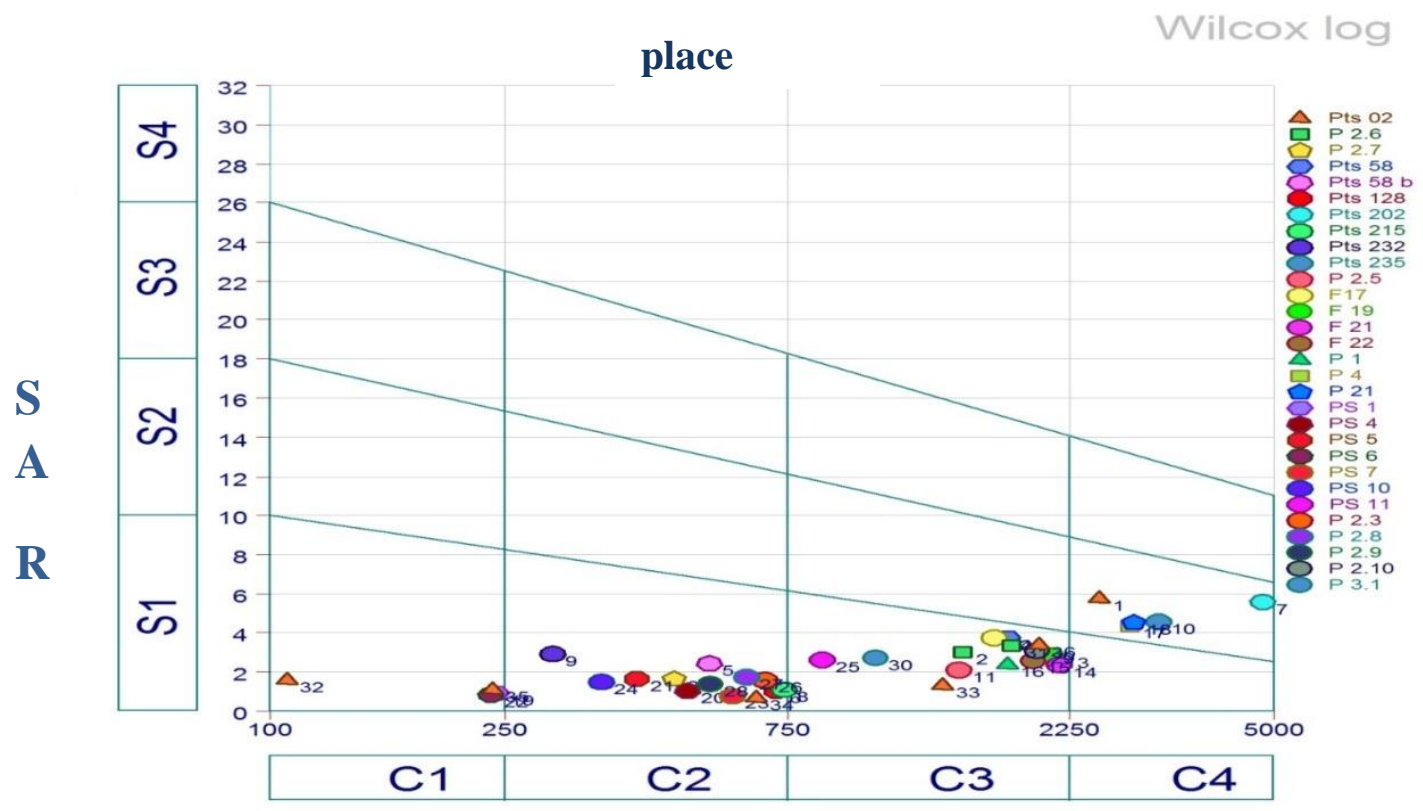

\section{Conductivitv in $\mathrm{uS} / \mathrm{cm}$}

Fig 5:-classification of water quality for irrigation (Wilcox Log)

The $\% \mathrm{Na}$ values calculated in the study area ranged from $23.9 \%$ to $72.08 \%$ (Table 4 ).

Table 4:-values of $\% \mathrm{Na}$ in water sample

\begin{tabular}{|c|c|c|}
\hline Networks name & Localities & $\%$ Na \\
\hline Pts 22 & Déni B. Ndao & 62.27 \\
\hline P 2.6 & Boune & 44.17 \\
\hline P 2.7 & Tivaoune Peulh & 39.81 \\
\hline Pts 58 & Mbeubeuss & 48.99 \\
\hline Pts 58 b & Mbeubeuss & 56.34 \\
\hline Pts 128 & Wayambame & 26.72 \\
\hline Pts 202 & Koumoune & 45.23 \\
\hline Pts 215 & Golam & 33.57 \\
\hline Pts 232 & Kaniack & 72.08 \\
\hline Pts 235 & Bambilor & 43.96 \\
\hline P 2.5 & Corniche Guédiawaye & 42.96 \\
\hline F17 & Marché Thiaroye & 52.54 \\
\hline F 19 & Thiaroye & 46.55 \\
\hline F 21 & Thiaroye & 46.10 \\
\hline F 22 & Thiaroye & 46.82 \\
\hline P 1 & Technopole & 50.17 \\
\hline P 4 & Pikine & 51.39 \\
\hline P 21 1 & Yeumbeul & 54.55 \\
\hline PS 4 & Sangalkam & 35.74 \\
\hline PS 5 & Santhe Mame Gor & 31.01 \\
\hline
\end{tabular}


The ranking of the water samples on the basis of $\% \mathrm{Na}$ are presented in Table 5.

Table 5:-classification of water quality according to $\% \mathrm{Na}$

\begin{tabular}{|l|c|c|c|}
\hline \multicolumn{1}{|c|}{ Class } & Rank & Number of samples & Percentage \\
\hline Excellent & $<20$ & 0 & 0 \\
\hline Good & $20-40$ & 4 & 25 \\
\hline Acceptable & $40-60$ & 14 & 66.7 \\
\hline Mediocre & $60-80$ & 3 & 8.3 \\
\hline Unfit & $>80$ & 0 & 0 \\
\hline
\end{tabular}

According to the classification given in Table 5, 25\% of the samples in the zone fall into the category good for irrigation. The acceptable category for irrigation is represented by $66.7 \%$ while $8.3 \%$ of the groundwater samples fall into the mediocre category.

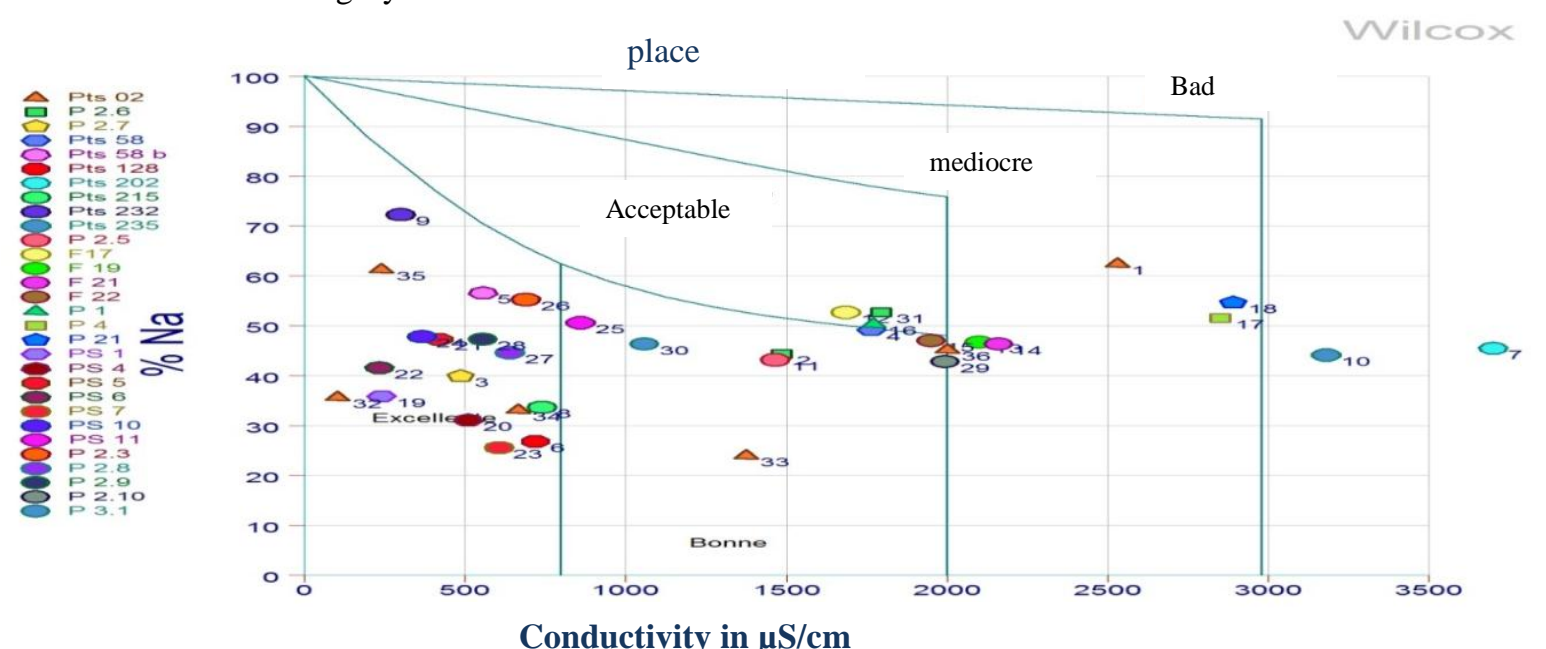

Fig 6:-Wilcox plot \% Na vs EC

The Wilcox plot (Fig. 6) plotted against \% Na and EC shows that $47.2 \%$ of the groundwater samples fall in the area of excellent to good water for irrigation. $11.1 \%$ of the waters are in the good to acceptable range. $19.4 \%$ fall in the acceptable range to mediocre. $16.7 \%$ in the mediocre field to bad and $5.6 \%$ fall in the bad field.

\section{Conclusion:-}

With the return to operation of boreholes that have been shut down, the State of Senegal plans to send pumped water to market gardeners in the Niayes area. While this may help to solve the problem of flooding in the area with the disappearance of water that hitherto stagnated because of the rise of the groundwater level, there may be another problem for them. Indeed, while it is clear that nitrate is a fertilizer for speculations, its presence in water, at certain proportions, could pose a problem of irrigation ability.

Thus, this work shows that all water from the Thiaroye aquifer is, on the one hand note usable for population consumption, and on the other hand not directly usable for agriculture. Pumping the abundant water from the Thiaroye grounwater to feed market gardeners and reduce the risk of flooding in the area, the idea as such is enticing, but it is important to recognize that after this study, it will be necessary in some areas, measures such as bringing these waters up to standard before being used for agriculture. Therefore, we can admit that the water resource of the Thiaroye aquifer in its entirety is still usable.

\section{Bibliography:-}

1. WHO: "Quality Guidelines for Drinking Water 1st Edition," Geneva, 1994.

2. DGPRE, 2010. "The groundwater of the peninsula of Cape Verde, their use for the water supply of Dakar", 58p.

3. SONES, 2012. "hydrochemical study of the Quaternary aquifer in the Dakar area",167p. 
4. NDAO Mariétou, (2012): Dynamics and environmental management from 1970 to 2010 of the wetlands of Senegal: study of land use by Niayes remote sensing with DjiddahThiaroye Kao (in Dakar), Mboro (in Thiès and Saint Louis). Ph D thesis in Geography. University Mirail-Toulouse II, 302 p.

5. DIAW E. B., Mamadou L. Lo, Mamadou Wade, Seydou Ndao, Ablaye Diallo, and Grégoire SISSOKO, (2016). Numerical modeling of solute transport: prediction of the risks of contamination of the Niayes aquifer (Senegal) by pesticides; International Journal of Innovation and Applied Studies, Vol. 17 No.4:1358-1372

6. Diompy, C. 2011 "study of the Thiaroye groundwater by numerical model", 72p.

7. Faye, M. 2013 "Contribution to the study of mobilization of water resources for food in Dakar: Diagnosis and perspectives", 123p.

8. J, R, e, Coll, "The analysis of water 8th edition," Dunod, Paris, 2005.1383p.

9. Cissé I., Use of pesticides in the horticultural production system in the Niayes area: the products and their impacts on the groundwater. PhD thesis postgraduate geography option environment. November $2000,187 \mathrm{p}+$ annexes.

10. Addo M. A., G.M. Okley, H.A. Affum, S. Acquah, J.K. Gbadago, Water Quality and Level of Some Heavy Metals in Water and Sediments of Kpeshie Lagoon, La-Accra, Ghana. Research Journal of Environmental and Earth Sciences 3(5): 487-497, 2011.

11. Ake G.E., Dongo K., Kouadio B.H., Dibi B., Saley M.B., Biemi J., (2009). Contribution of DRASTIC and GOD Intrinsic Vulnerability Methods to the Nitrate Pollution Study in the Bonoua region (South East of Ivory Coast). European Journal of Scientific Research, ISSN 1450-216X, Vol.31 No.1 (2009): 157-171.

12. AFNOR, 1997. French Agency for Standardization, "Water quality. Volume 1: Terminology, sampling and evaluation of methods ", 3rd edition, Paris, France.439p.

13. AYERS, R., S. \& WESTCOT, D.W. 1988. Water quality in agriculture. FAO Irrigation and Drainage Bulletin, 29, 1: 165, FAO, Rome.

14. RICHARDS, L. A., 1954. Diagnosis and improvement of saline and alkali soils. Agric. Handbook 60, USDA, Washington D.C.160 p.

15. DEBIECHE T.H. (2002). Evolution of water quality (salinity, nitrogen and heavy metals) as a result of salt, agricultural and industrial pollution.131p.

16. ROUABHIA A., BAALI F., KHERICI N., DJABRI L. (2004). Vulnerability and risk of groundwater pollution of the Miocene sands of the plain of El MA EL Abiod (Algeria), Revue Sécheresse Vol.15, $\mathrm{n}^{\circ} 4$.

17. Aller, L.T., Bennett, J.H., Lehr, R.J., Petty, R.I., Hackett, G., (1987). DRASTIC, a standardized system for evaluation groundwater pollution using hydrogeologic settings, US Environmental Protection Agency 600/2/035, Washington, DC, 455pp.

18. Ribeiro, L., Serra, E., Paralta, E., Nascimento, J., (2003).Nitrate pollution in hardrock formations: Vulnerability and Risk evaluation by geomathematical methods in Serpa Brinches aquifer (South Portugal). In: Krasny, J., Hrkal, Z., and Bruthans, J. (eds.) Proceedings of IAH International Conference on Groundwater in Fractured Rocks, pp. 377-378. Prague, Czech Republic, IHP-VI, Series on Groundwater no. 7, UNESCO, Paris.

19. ROUABHIA A., BAALI F., FEHDI Ch., KHERICI N., DJABRI L. (2008): Hydrochemical and isotopic investigation of a sandstone aquifer groundwater in a semi arid region, El Ma El Abiod, Algeria. Journal of environmental geology (Springer) Environ Geol. No. 254 DOI: 10.1007 / s00254-008-1451-5.

20. ROUABHIA A., DJABRI L. (2004): Irrigation and the risk of saline pollution, example of groundwater in the miocene aquifere of el ma el abiod; University Center of Tébessa. Algeria BP. 34-A. 12004 Nahda-Poste. Tebessa.

21. Russo, D., Determination soil hydraulic properties by parameter estimation: on the selection of a model for the hydraulic properties. Water resources research, vol. 24, n³: pp. 453-459, 1988.

22. Ndiaye B., Diallo M.L., Diaw E.B., Characterization of Soil Fertilization in the Niayes Zone - Report of Research Farmer Entrepreneurship Support Project (PAEP) in the Niayes region (Senegal) - 54 pages, 2000.

23. ROUABHIA A. (2006) Vulnerability and risk of water pollution subsoil of the Miocene sands of the El Ma El Abiod plain. N. Algeria. PhD Thesis in Science, 210p, University of Annaba, Algeria.

24. Wilcox L.V (1948), The quality of water for agricultural use. US Dept Agriculture Tech. Bull. 1962, Washington DC. 